\title{
Indian Expert Opinion on Cancer Care during COVID-19 Pandemic
}

\author{
Ashok K. Vaid ${ }^{1}$ Hemant Malhotra ${ }^{2}$ Raja Thirumalairaj ${ }^{3}$ Reena Nair ${ }^{4}$ Ajay Bapna ${ }^{5}$ \\ Senthil J. Rajappa ${ }^{6} \quad$ S. P. Somashekhar ${ }^{7}$ Chanchal Goswami ${ }^{8} \quad$ Jyoti Bajpai ${ }^{9}$
}

${ }^{1}$ Department of Medical Oncology and Hematology, Medanta Cancer Institute, Medanta-The Medicity, Gurgaon, Haryana, India

${ }^{2}$ Department of Medical Oncology, Sri Ram Cancer Center,

Mahatma Gandhi University of Medical Sciences and Technology, Jaipur, Rajasthan, India

${ }^{3}$ Department of Medical Oncology, Apollo Hospitals, Chennai, Tamil Nadu, India

${ }^{4}$ Department of Clinical Hematology, Tata Medical Centre, Kolkata, West Bengal, India

${ }^{5}$ Department of Medical Oncology, Bhagwan Mahaveer Cancer Hospital and Research Centre, Jaipur, Rajasthan, India

${ }^{6}$ Department of Oncology, Basavatarakam Indo American Cancer Hospital and Research Institute, Hyderabad, Telangana, India

${ }^{7}$ Department of Surgical Oncology, Manipal Comprehensive Cancer Center, Manipal Hospital, Bangalore, Karnataka, India

${ }^{8}$ Oncology Services, Medica Institute of Breast Diseases, Medica Superspecialty Hospital, Kolkata, West Bengal, India

${ }^{9}$ Department of Medical Oncology, Tata Memorial Hospital/Center, Mumbai, Maharashtra, India

\section{South Asian J Cancer 2021;10:9-18.}

Address for correspondence Ashok K. Vaid, DM, Department of Medical Oncology and Hematology, Medanta Cancer Institute, Medanta-The Medicity, Sector-38, Gurgaon, Haryana 122001, India (e-mail: akvaid@yahoo.com).

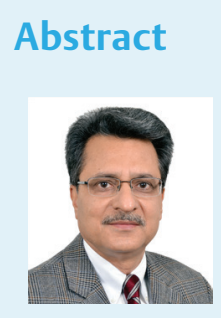

Dr. Ashok K. Vaid
Coronavirus pandemic has increased human disease burden, as well as economic distress globally. Being in an immunocompromised state, patients with cancer comprise an important at-risk population for novel coronavirus disease 2019 (COVID-19) infection. It is necessary to modify individualized clinical management for every cancer patient in the context of the ongoing COVID-19 pandemic. Simultaneously, additional safety precautions for the cancer care providers are mandatory. This review will provide general recommendations in the Indian context optimizing the same.

Keywords

India, oncology management, recommendations, patient safety

\section{Introduction}

Public health is facing an unprecedented crisis as 7,390,702 confirmed cases of novel coronavirus disease 2019 (COVID-19), including 417,731 deaths, have been reported globally as of June $12,2020 .{ }^{1}$ Corresponding figures for India are 289,036 cases and 8,498 deaths, indicating that Indians might have a lower mortality. ${ }^{2,3}$

There is limited published data related to COVID-19 and cancer patients. China reported that patients with cancer had a

\section{DOI https://doi.org/10.1055/s-0041-1727560 ISSN 2278-330X}

How to cite this article: Vaid A. K, Malhotra $H$, Thirumalairaj $R$, et al. J. Indian Expert Opinion on Cancer Care during. South Asian J Cancer 2021;10(1):9-18. two-fold higher chance of COVID-19 infection, several comorbid conditions (diabetes, cardiovascular diseases, and hypertension) elevating the risk. ${ }^{4,5}$ Another case series from Wuhan, China, showed that patients who received latest antitumor therapy within 2 weeks of COVID-19 diagnosis were more prone to develop severe events. ${ }^{6}$ Meta-analysis of 11 studies suggested that of all patients infected with COVID-19, 2.0\% had underlying cancer (95\% confidence interval [CI]: 2.0-3.0\%; $\left.I^{2}=83.2 \%\right){ }^{7}$ The Indian Council of Medical Research (ICMR)'s laboratory surveillance for COVID-19 showed that among the

(c) 2021. MedIntel Services Pvt Ltd.

This is an open access article published by Thieme under the terms of the Creative Commons Attribution-NonDerivative-NonCommercial-License, permitting copying and reproduction so long as the original work is given appropriate credit. Contents may not be used for commercial purposes, or adapted, remixed, transformed or built upon. (https://creativecommons.org/licenses/by-nc-nd/4.0/).

Thieme Medical and Scientific Publishers Private Ltd A-12, Second Floor, Sector -2, NOIDA -201301, India 
positive cases ( $n=40,184$ ), $25.3 \%$ were asymptomatic family contacts and $10.6 \%$ were symptomatic contacts. ${ }^{8}$ These numbers are likely to increase and hence, India-specific cancer guidelines is the need of the hour.

\section{Methods}

A group of nine Indian subject experts (medical, surgical, radiation, and hemato oncologists) met virtually (video conference) to discuss available data, personal experience, and developed the consensus review document. The draft was circulated electronically, inputs obtained and modified as appropriate, till the final document was approved by all authors.

\section{Risk Factors}

It is estimated that excess cancer deaths during COVID-19 pandemic are likely to be 6,270 in England and 33,890 in the United States. ${ }^{9}$ Individuals at higher risk of COVID-19 infection and associated mortality among cancer cohort are summarized in -Fig. $1 .^{10}$

\section{Practical Challenges and General Recommendations during COVID-19 Pandemic}

The practical challenges faced by Indian oncology community and cancer hospitals are numerous. ${ }^{11,13}$

Several important ones are described in - Table 1 . Testing for COVID-19 among cancer patients should follow a triage system including thermal screening at point of entry, evaluation of susceptibility, and appropriate segregation bet-ween COVID-19 designated and non-COVID-19 healthcare facilities (-Fig. 2). ${ }^{13,14}$ The committee recommended nonsymptomatic (for COVID-19) patients to receive daycare treatment on the same day (without waiting for results of COVID-19 tests). The committee's opinion was that it was not feasible to do reverse-transcription polymerase chain reaction (RT-PCR) severe acute respiratory syndrome-coronavirus-2 (SARS-CoV-2) testing for all cancer patients in India, ${ }^{14}$ limiting its application only to patients undergoing aerosol-generating procedure or those with symptoms suggestive of COVID-19 infection (such as fever, coughing, sore throat, difficulty in breathing, muscle pain, tiredness, anosmia, and dysgeusia). A separate set of recommendations should be developed by each hospital for X-ray, computed tomography (CT), pulmonary function tests, and other biological tests. All cancer patients must be told to follow prevailing government regulations against COVID-19 (including World Health Organization recommendations). ${ }^{15}$

\section{Cancer Patients' Treatment Decision and Prioritization}

Management of individual cancer patients should be prioritized based on their risk category. ${ }^{14}$

High priority: life-threatening condition, clinically unstable, and/or the benefit justifies high-priority intervention (significant overall survival gain and/or substantial improvement in quality of life [QoL]). Should continue receiving standard of care as before.

Medium priority: noncritical. Delay in definitive therapy by up to 6 weeks may be permitted as appropriate without change in overall outcome.

Low priority: stable. Temporarily delay anticancer management for the duration of the COVID-19 pandemic, provided there is no or low impact on survival benefit or QoL. ${ }^{14}$

Hospital visits and elective admissions should be minimized. Noncritical elective surgical procedures, adjuvant/neoadjuvant chemotherapy, and/or radiotherapy
On chemotherapy, or

chemotherapy in the last 3 months

\section{Bone marrow or stem cell transplants in the last 6 months}
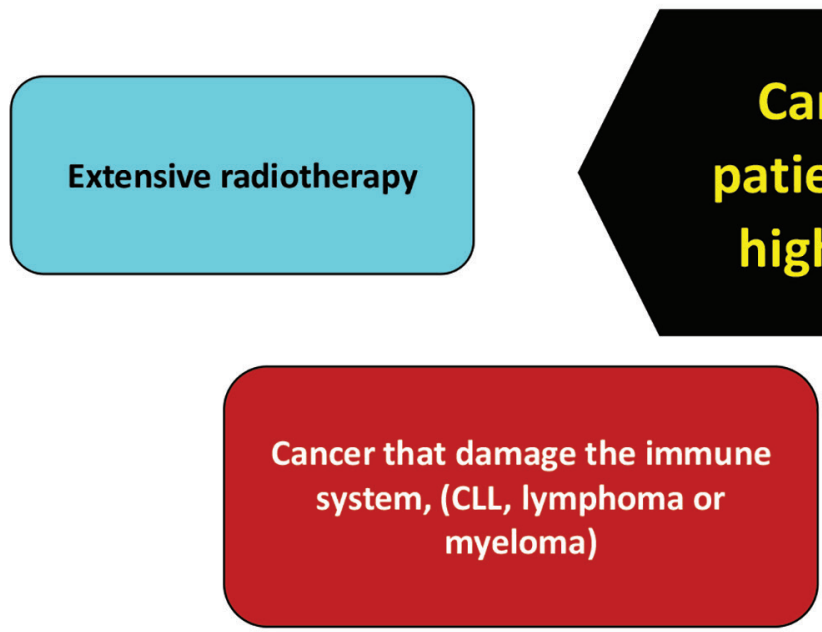

With an impaired immune system

- Leukocytopaenia,

- Low immunoglobulin levels

- Long lasting immunosuppression

Fig. 1 Individuals at high risk of COVID-19 infection and associated mortality among cancer cohort. CLL, chronic lymphocytic leukemia; COVID-19, novel coronavirus disease 2019. 
Table 1 Practical challenges during COVID-19 pandemic

\begin{tabular}{|l|}
\hline Practical challenges during CoVID-19 pandemic: meeting discussions \\
\hline Patient perspective \\
\hline - Management of patients from remote areas where there are no cancer hospitals or cancer hospitals with limited treatment \\
\hline - Impact of lockdown on local, intra and interstate travel resulting in non-approachable accessibility of the treatment facilities by \\
many cancer patients from rural areas \\
\hline - Under the scenario of severe resource constraints, treatment might only be possible in oncological emergencies \\
\hline Healthcare infrastructure perspective \\
\hline - Potential shortage of personal protective equipments, such as masks, gowns, and gloves \\
\hline - Potential shortage of hospital beds, intensive care unit beds, and ventilators \\
\hline - Inability to maximize social distancing among our patients, colleagues, and staff due to humongous patient load in outpatient \\
departments and space constraint \\
\hline - Human resource constraints: potential shortage of hospital personnel due to sickness, quarantine, and duties at home \\
\hline Nononcology COVID-19 cases can potentially overburden current health-system capacity in the near future \\
\hline
\end{tabular}

Abbreviation: COVID-19, novel coronavirus disease 2019.

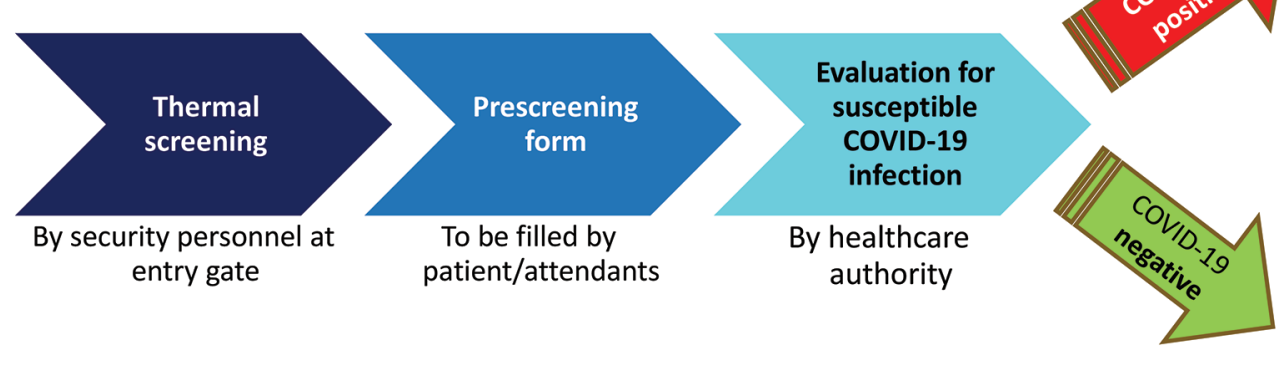

Fig. 2 Triage system for screening of cancer patients.

may be postponed temporarily (if feasible) based on local COVID-19 circumstances. Where treatment is to be initiated or continued, strict adherence to the COVID-19 prevention and screening strategy is mandatory. When the cancer patient is suspected or confirmed to have the COVID-19 infection, management needs to be individualized ( - Fig. 3 ). ${ }^{16}$

A multidisciplinary tumor board should decide whether patient has indolent/early stage disease where wait and watch policy is appropriate, whether intravenous therapies can be temporarily replaced with oral therapies, whether adjuvant therapy can allow postponement of definitive surgery, whether palliative therapy can be delayed/postponed/avoided, or whether routine follow-up visits can be postponed for asymptomatic patients who have completed their anti cancer treatment. $(- \text { Fig. } 4)^{14,16}$ Treatment of cancer patients must not be postponed indefinitely. Remote monitoring using telemedicine should be used wherever possible. Instructions should be given to allow investigations (e.g., CBC, blood biochemistry, and CT scan) and procurement of oral medication (prescriptions) closer to home. No emergency treatment (chemotherapy, radiation therapy, or surgery) should be denied. Intensive treatment like planned allogeneic stem-cell transplantations can be delayed where disease control can be achieved with alternative treatment methods. ${ }^{14}$ The National Institute for Health and Care Excellence (NICE) guidelines provide recommendations for prioritizing systemic anticancer therapy, radiotherapy treatments, and hematopoietic stem-cell transplantation as shown in - Table 2.17-20

At all times, protection of the cancer care providers must be diligently followed as per prevailing regulations and standard operating procedures (SOPs). ${ }^{14,21}$

\section{Responsibilities of Oncologists and the Oncology Community}

Disruption in routine oncology services should be minimized. Awareness and screening programs should continue with the addition of education and implementation of preventive 


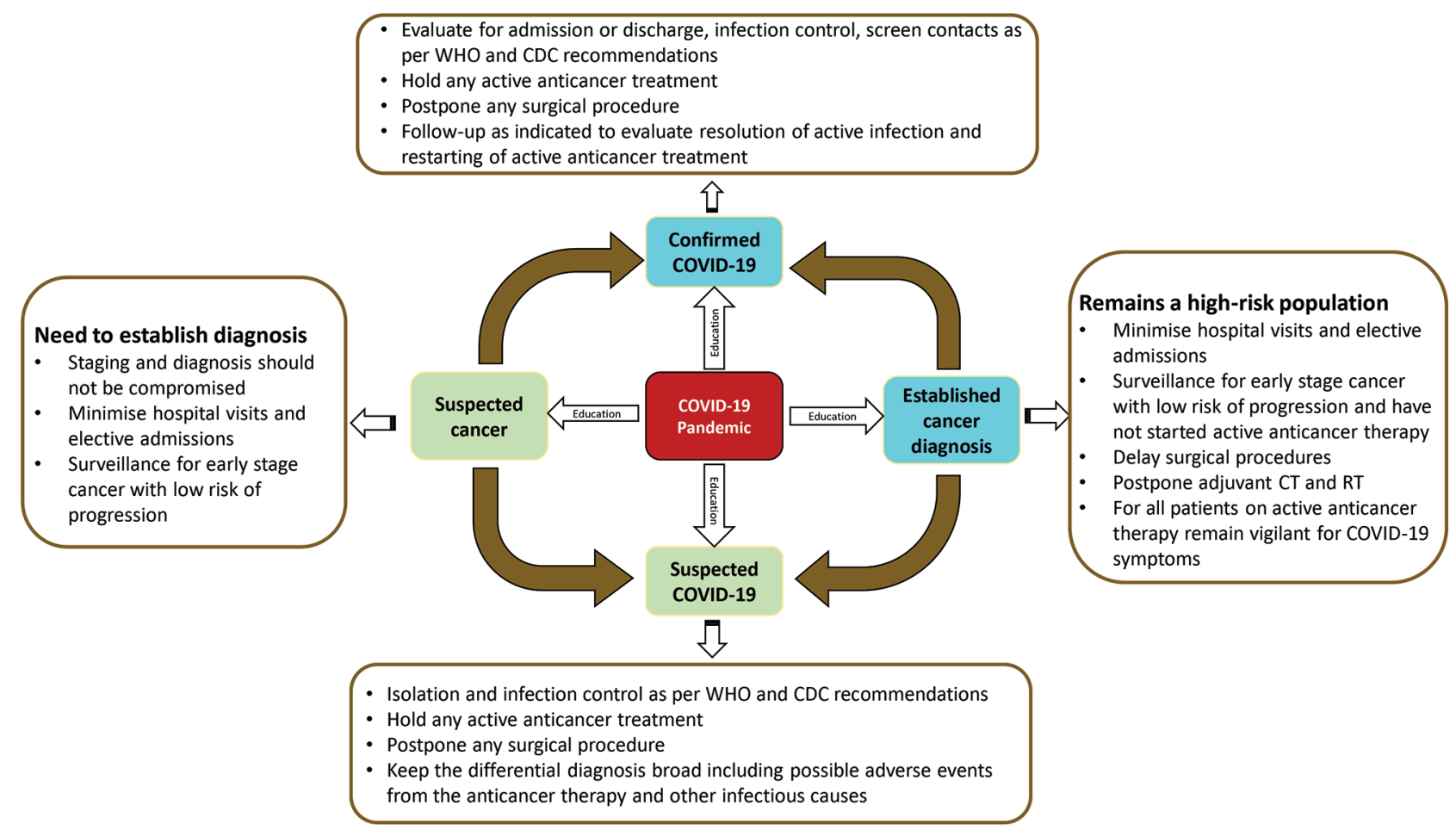

Fig. 3 Practical approach to the management of cancer patients during COVID-19 pandemic (Adapted from: Al-Shamsi et al). ${ }^{16}$ CDC, Centers for Disease Control and Prevention; COVID-19, novel coronavirus disease 2019; CT, chemotherapy; RT, radiotherapy; WHO, World Health Organization.

\section{Solid tumour cancer diagnosis during pandemic}

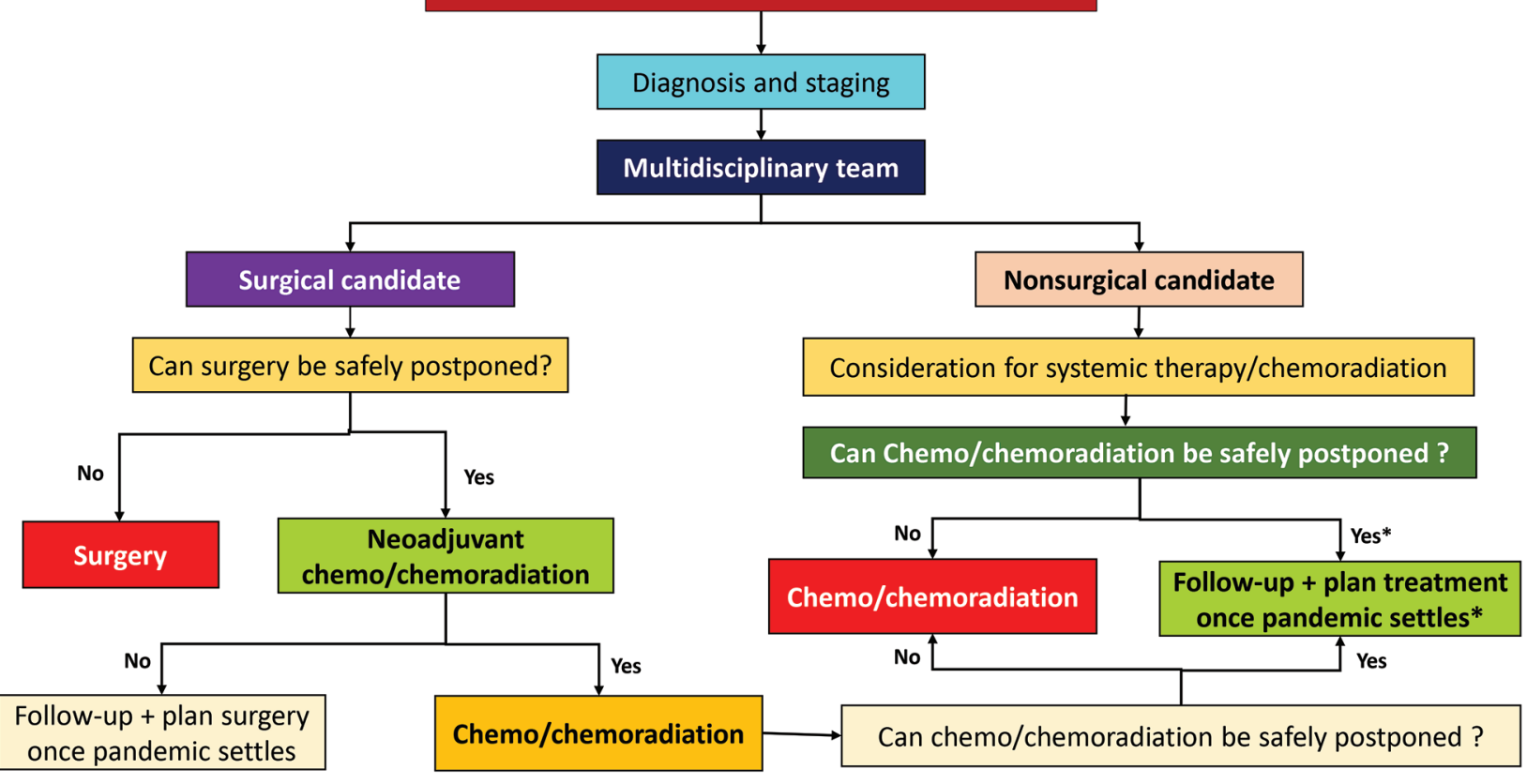

* Systemic therapy or chemoradiation

Fig. 4 Management of solid tumors during COVID-19 pandemic (Adapted from: Al-Shamsi et al). ${ }^{16}$

measures against COVID-19. Scarce resources should be reallocated if necessary to maximize health benefits. The American Society of Clinical Oncology (ASCO) also recommends that oncologists should communicate the new plan to their patients with compassion and honesty. ${ }^{22}$ Psychological support should be offered where necessary; COVID-19 adding to the emotional distress, anxiety, feeling of despair, and fear of death commonly experienced by cancer patients. Patients might have concerns about uncertainty of receiving their cancer treatment on time, delay in life-saving treatments due 
Table 2 Prioritizing systemic anticancer treatments, radiotherapy treatments, and hematopoietic stem-cell transplantation (NICE guidelines)

\begin{tabular}{|c|c|c|c|}
\hline $\begin{array}{l}\text { Priority } \\
\text { level }\end{array}$ & Systemic anticancer treatments ${ }^{17}$ & Radiotherapy treatments $^{18}$ & $\begin{array}{l}\text { Hematopoietic stem-cell } \\
\text { transplantation }^{19}\end{array}$ \\
\hline 1 & $\begin{array}{l}\text { Curative treatment with a high (more } \\
\text { than } 50 \% \text { ) chance of success } \\
\text { Adjuvant or neoadjuvant treatment } \\
\text { which adds at least } 50 \% \text { chance of cure } \\
\text { to surgery or radiotherapy alone or } \\
\text { treatment given at relapse }\end{array}$ & $\begin{array}{l}\text { Radical radiotherapy or chemoradio- } \\
\text { therapy with curative intent, if: } \\
\text { - The patient has a category } 1 \text { (rapidly } \\
\text { proliferating) tumor } \\
\text { - Treatment has already started } \\
\text { - There is little or no possibility of } \\
\text { compensating for treatment gaps } \\
\text { External beam radiotherapy with subse- } \\
\text { quent brachytherapy, if: } \\
\text { - The patient has a category } 1 \text { (rapidly } \\
\text { proliferating) tumor } \\
\text { - External beam radiotherapy has } \\
\text { already started } \\
\text { Radiotherapy that has not started yet, if: } \\
\text { - The patient has a category } 1 \text { (rapidly } \\
\text { proliferating) tumor } \\
\text { - They would normally start treat- } \\
\text { ment, based on clinical need or cur- } \\
\text { rent cancer treatment waiting times }\end{array}$ & $\begin{array}{l}\text { Urgent allogeneic HSCT where delaying } \\
\text { the procedure presents a high risk } \\
\text { of disease progression, morbidity, or } \\
\text { mortality }\end{array}$ \\
\hline 2 & $\begin{array}{l}\text { Curative treatment with an interme- } \\
\text { diate (20-50\%) chance of success } \\
\text { adjuvant or neoadjuvant treatment } \\
\text { which adds } 20 \text { to } 50 \% \text { chance of cure } \\
\text { to surgery or radiotherapy alone or } \\
\text { treatment given at relapse }\end{array}$ & $\begin{array}{l}\text { Urgent palliative radiotherapy, for } \\
\text { patients with malignant spinal cord } \\
\text { compression who have salvageable } \\
\text { neurological function }\end{array}$ & $\begin{array}{l}\text { High-grade lymphomas and other } \\
\text { urgent cases needing autologous } \\
\text { HSCT for curative intent (e.g., diffuse } \\
\text { large B-cell lymphoma and Hodgkin's } \\
\text { lymphomas) }\end{array}$ \\
\hline 3 & $\begin{array}{l}\text { Curative treatment with a low } \\
\text { (10-20\%) chance of success } \\
\text { Adjuvant or neoadjuvant treatment } \\
\text { which adds } 10-20 \% \text { chance of cure to } \\
\text { surgery or radiotherapy alone or treat- } \\
\text { ment given at relapse } \\
\text { Noncurative treatment with a high } \\
\text { (more than } 50 \% \text { ) chance of more than } \\
1 \text {-year extension to life }\end{array}$ & $\begin{array}{l}\text { Radical radiotherapy for a category } 2 \\
\text { (less aggressive) tumor, if radiotherapy } \\
\text { is the first treatment with curative } \\
\text { intent. Postoperative radiotherapy, if: } \\
\text { - The patient has a tumor with aggres- } \\
\text { sive biology or } \\
\text { - They have had surgery, but there is } \\
\text { known residual disease }\end{array}$ & $\begin{array}{l}\text { Chronic conditions including most } \\
\text { non-malignant indications and low-risk } \\
\text { malignant indications for allogeneic } \\
\text { HSCT (most should be deferred until } \\
\text { the risks associated with the COVID-19 } \\
\text { pandemic have passed) }\end{array}$ \\
\hline 4 & $\begin{array}{l}\text { Curative treatment with a very low } \\
(0-10 \%) \text { chance of success } \\
\text { Adjuvant or neoadjuvant treatment } \\
\text { which adds less than } 10 \% \text { chance of } \\
\text { cure to surgery or radiotherapy alone } \\
\text { or treatment given at relapse } \\
\text { Noncurative treatment with an inter- } \\
\text { mediate }(15-50 \%) \text { chance of more than } \\
1 \text {-year extension to life }\end{array}$ & $\begin{array}{l}\text { Palliative radiotherapy, where improv- } \\
\text { ing symptoms would reduce the need } \\
\text { for other interventions }\end{array}$ & $\begin{array}{l}\text { Allogeneic HSCT recipients with a } \\
\text { relatively low predicted survival (e.g., } \\
20-30 \% \text { at } 5 \text { years based on pre-HSCT } \\
\text { characteristics; all but exceptional cases } \\
\text { should be deferred until the risks asso- } \\
\text { ciated with the COVID-19 pandemic } \\
\text { have passed) }\end{array}$ \\
\hline 5 & $\begin{array}{l}\text { Noncurative treatment with a high } \\
\text { (more than } 50 \% \text { ) chance of palliation or } \\
\text { temporary tumor control and less than } \\
1 \text {-year expected extension to life }\end{array}$ & $\begin{array}{l}\text { Adjuvant radiotherapy, if: } \\
\text { - The disease has been completely } \\
\text { resected } \\
\text { - There is a less than } 20 \% \text { risk of local } \\
\text { recurrence at } 10 \text { years } \\
\text { Radical radiotherapy for prostate } \\
\text { cancer, in patients having neoadjuvant } \\
\text { hormone therapy }\end{array}$ & $\begin{array}{l}\text { Autologous HSCT for myeloma, low- } \\
\text { grade lymphoproliferative diseases, } \\
\text { and nonmalignant indications (all but } \\
\text { exceptional cases should be deferred } \\
\text { until the risks associated with the } \\
\text { COVID-19 pandemic have passed) }\end{array}$ \\
\hline 6 & $\begin{array}{l}\text { Noncurative treatment with an inter- } \\
\text { mediate (15-50\%) chance of palliation } \\
\text { or temporary tumor control and less } \\
\text { than } 1 \text {-year expected extension to life }\end{array}$ & NIL & NIL \\
\hline
\end{tabular}

Abbreviations: COVID-19, novel coronavirus disease 2019; HSCT, hematopoietic stem-cell transplantation; NICE, National Institute for Health and Care Excellence.

to lockdown restrictions, social distancing reducing family support, risk of getting COVID-19 infection while in hospitals, and subsequent effect on their survival outcomes. While clinical trials are important, they will lose priority in the fight against the COVID-19 pandemic. Patients being consented for or already ongoing on clinical studies might need SOPs to be 
modified to make participation more patient friendly without compromising on the integrity of the study protocol. ${ }^{23-27}$

Based on the ASCO suggestions, the committee recommended to (1) keep participants informed about changes to trials and their care and remind participants to alert their research team about changes to their health; (2) develop formal COVID-19 standard operating procedures for clinical trials; (3) promote telehealth virtual visits for patients; (4) implement all aspects of patient review through patient portal, email, phone, video; (5) use remote safety laboratory testing, where feasible; and (6) shipment of oral study medication directly to patients. ${ }^{23}$

\section{Cancer-Specific Recommendations in the Indian Context}

According to Globocan 2018 data, the five most common cancers in India are breast cancer (14\%), oral cavity cancer (10.4\%), cervix uteri (8.4\%), lung cancer (5.9\%), and stomach cancer (5\%). Other cancers such as head and neck cancers, prostate cancer, colorectal cancer, leukemias, and lymphomas also significantly contribute to the cancer burden of India. ${ }^{28}$ Several global organizations have published guidelines for the management of cancer patients during this COVID-19 pandemic. This committee has recommended their adoption in the Indian settings with appropriate modifications.

\section{Breast Cancer}

Surgical oncology high priority includes patients who have completed neoadjuvant chemotherapy or who have progressive disease during neoadjuvant treatment, patients with breast abscess who cannot be drained at bedside, and patients whose diagnostic dilemma requires excisional biopsy. For patients with invasive cancer or those who are pregnant, a multidisciplinary tumor board will need to take individualized decision based on the risk benefit of surgery versus other modalities of treatment. Medium priority should be assigned to patients with clinically low-risk primary breast cancer (e.g., stage I/II estrogen receptor [ER]-positive/progesterone receptor [PR]-positive/human epidermal growth factor receptor 2 (HER2)-negative, and low-grade/low proliferative index tumors). They can be commenced on neoadjuvant/preoperative endocrine therapy (according to menopausal status) and definitive surgery delayed. For patients with triple-negative breast cancer or HER2-positive disease, neoadjuvant chemotherapy or HER2-targeted treatment is recommended. Low priority shall include patients with benign lesions (fibroadenomas, atypia, and papillomas), those opting for prophylactic surgery (e.g., asymptomatic with risk of hereditary cancers) and those requiring high-risk procedures (e.g., reconstruction after mastectomy). Patients with ER + ductal carcinoma in situ (DCIS) also fall in this category and their surgery may be delayed until the COVID-19 pandemic settles down. For patients with malignant phyllodes or sarcomas, decision regarding surgery needs to be individualized. ${ }^{29-31}$

Radiation oncology of high priority includes patients requiring palliative treatment for bleeding/painful inoperable breast mass; for adjuvant postoperative radiotherapy in high-risk breast cancer patients (inflammatory disease at diagnosis, node-positive disease, triple-negative breast cancer, HER2-positive breast cancer, residual disease at surgery, and age $<40$ years). Medium priority should be assigned for adjuvant postoperative radiotherapy in patients with low- 1 intermediate-risk breast cancer (age: 40-65 years, stage I/II luminal cancer, ER-positive, regardless of nodal status or positive margins). Use of hypofractionated regimens should be considered to reduce hospital visits. Endocrine therapy may be started during the waiting interval. Low priority patients are those with low-risk breast cancer (age: $>70$ years, lowrisk stage I, and ER-positive/HER2-negative breast cancer). Adjuvant endocrine therapy can be commenced while postponing radiotherapy. Locally advanced HR-negative cases may be offered neoadjuvant chemotherapy. ${ }^{30}$

In medical oncology, oral endocrine agents, such as tamoxifen and aromatase inhibitors, can be safely continued. Patients progressing on neoadjuvant therapy should be referred to surgery, radiation, or given second-line systemic therapy. Patients with clinical anatomic stage 1 or 2 ER-positive/HER-negative should be administered neoadjuvant endocrine therapy surgery postponed for 6 to 12 months. Aromatase inhibitors should be preferred over tamoxifen for neoadjuvant endocrine therapy. The addition of oral-targeted agents to endocrine therapy may be delayed in first-line therapy or in situations where endocrine therapy alone is providing effective tumor control. Administration of granulocyte colony-stimulating factor (G-CSF) growth factor and dexamethasone should be limited, when possible.

\section{Head and Neck Cancers}

Updated Indian Association of Surgical Oncology (IASO) guidelines for head and neck cancers recommend procedures, such as tracheostomy, carotid artery ligation, or endoscopic NG tube insertion/stenting, for emergencies like stridor, bleeds, and dysphagia. Postponing of all the cosmetic reconstruction surgeries is recommended. T1 and T2 lesions should be operated with minimal hospitalization. Patients suitable for neoadjuvant therapy should be managed accordingly. Treatment of slowly progressing cancers including thyroid, parotid, and basal-cell carcinoma should be deferred. Patients with locally aggressive thyroid cancers/local invasion/airway compression should be immediately treated with surgery. Early surgery may also be considered in cases of uncontrolled hyperparathyroidism. Neoadjuvant radiotherapy and/or chemotherapy should be preferred for patients with esophagus cancers; surgery may be postponed by 3 weeks by using neoadjuvant treatment. ${ }^{30}$

\section{Lung Cancer}

Most lung cancers are diagnosed in advanced (inoperable) stage and can be continued on standard treatment with chemotherapy, radiotherapy, and/or targeted therapy. In patients with stage-I to -III lung cancers, a multidisciplinary tumor board should decide regarding surgery. High priority for surgical oncology includes drainage \pm pleurodesis for pleural effusion, pericardial effusion, tamponade risk, and evacuation 
of empyema-abscess, T2N0 tumors, resectable T3/T4 tumors, and resectable N1/N2 disease. Medium priority is assigned to patients with resectable nonsmall-cell lung cancer (NSCLC) with T1aN0 disease, where lung nodule(s) is an incidental finding (provided solid nodule $>500 \mathrm{~mm}^{3}$; pleural-based solid nodule $>10 \mathrm{~mm}$; solid component $>500 \mathrm{~mm}^{3}$ in partially solid nodule; known volume doubling time $<400$ days, and there is new solid component in preexisting nonsolid nodule). Low-priority cases include likely benign conditions. Recommendations for medical oncology in patients with early stage, locally advanced, and metastatic lung cancers have been summarized in - Table 3. Potential regimen alterations for NSCLC includes oral therapy (e.g., oral tyrosine kinase inhibitors [TKIs], oral etoposide, oral topotecan, and oral temozolomide) Patients with progressive disease can be evaluated with liquid biopsy instead of tissue biopsy if appropriate. ${ }^{31-33}$

\section{Hematological Malignancies}

Hematological malignancies can be divided into three categories according to intent of therapy, potentially curable, controllable, and palliative. Potentially curable leukemias and high-grade lymphomas should be treated using standard protocols without compromise in dose intensity. Growth factors, as well as supportive care, must be used appropriately during therapy. The lymphoma/leukemia/myeloma treatment recommendations in the era of COVID-19 are summarized in - Table $4.34,35$

In patients with early-stage Hodgkin's lymphoma, baseline positron emission tomography (PET) scan and interim PET scan should be utilized to optimize the number of standard ABVD (doxorubicin, bleomycin, vinblastine, and dacarbazine) chemotherapy cycles required. Intensive BEACOPP regimen (bleomycin, etoposide, doxorubicin hydrochloride, cyclophosphamide, vincristine, procarbazine, and prednisone) should be used upfront only for advanced disease or those with suboptimal response to two to three cycles of standard ABVD. Radiation therapy can be avoided and alternative regimens can be tried to reduce repeated hospital visits.

In case of relapsed leukemias and lymphomas, consider the use of outpatient-based salvage therapy (e.g.,

Table 3 Recommendations for lung cancer medical oncology ${ }^{32}$

\begin{tabular}{|c|c|c|c|}
\hline Levels & Early stage & Locally advanced stage & Metastatic \\
\hline High & $\begin{array}{l}\text { - Concomitant chemoradiotherapy } \\
\text { for SCLC limited disease stage I/II } \\
\text { - Neoadjuvant chemotherapy } \\
\text { (enabling deferral of surgery by } 3 \\
\text { months) in clinical stage II } \\
\text { - Delivery of adjuvant chemotherapy } \\
\text { in T3/4 or N2 disease for young (<65 } \\
\text { years old) and fit patients } \\
\text { - G-CSF use if febrile neutropenia risk } \\
\text { evaluated to be }>10-15 \%\end{array}$ & $\begin{array}{l}\text { - Concomitant chemo- } \\
\text { radiotherapy for SCLC } \\
\text { limited disease stage III } \\
\text { - Concomitant or sequen- } \\
\text { tial chemoradiotherapy } \\
\text { for inoperable NSCLC } \\
\text { Stage III } \\
\text { - Starting consolidation } \\
\text { durvalumab (within } \\
42 \text { days) } \\
\text { - Neoadjuvant chemother- } \\
\text { apy in clinical stage III } \\
\text { - G-CSF use if febrile neu- } \\
\text { tropenia risk evaluated to } \\
\text { be }>10-15 \%\end{array}$ & $\begin{array}{l}\text { - First-line treatment including chemotherapy, } \\
\text { chemotherapy plus IO, IO alone or TKIs to } \\
\text { improve prognosis, cancer-related symptoms } \\
\text { and QoL } \\
\text { - Start second-line chemotherapy or IO in symp- } \\
\text { tomatic and progressive disease patients } \\
\text { - Start } 2 \text { nd-line TKI in progressive disease patients } \\
\text { - G-CSF use has to be considered if despite opti- } \\
\text { mal dose modification, risk of febrile neutrope- } \\
\text { nia is }>10 \% \\
\text { - Anti-PD-(L) } 1 \text { scheduled cycles may be modified/ } \\
\text { delayed to reduce clinical visits }\end{array}$ \\
\hline Medium & $\begin{array}{l}\text { - Adjuvant chemotherapy in T2b- } \\
\text { T3N0 or N1 disease should be dis- } \\
\text { cussed with patients, considering } \\
\text { clinical features and prognosis } \\
\text { - Medical follow-up between two } \\
\text { cycles should be performed only if } \\
\text { necessary and by telephone } \\
\text { - Blood check between two cycles } \\
\text { should be performed only if neces- } \\
\text { sary and at home if possible }\end{array}$ & $\begin{array}{l}\text { - Medical follow-up } \\
\text { between two cycles } \\
\text { should be performed } \\
\text { only if necessary and by } \\
\text { telephone } \\
\text { - Blood check between } \\
\text { two cycles should be per- } \\
\text { formed only if necessary } \\
\text { and at home if possible }\end{array}$ & $\begin{array}{l}\text { - Start 2nd and beyond line chemotherapy or IO in } \\
\text { asymptomatic patients, in absence of threaten- } \\
\text { ing disease (volume/location) } \\
\text { - Consider, when feasible, oral chemotherapy } \\
\text { treatment instead of intravenous (etoposide, } \\
\text { vinorelbine) to reduce hospital visits } \\
\text { - Medical follow-up between two cycles by } \\
\text { telephone } \\
\text { - Blood check between two cycles should be per- } \\
\text { formed only if necessary and at home if possible } \\
\text { - For patients ongoing with IO from more than } \\
12 / 18 \text { months, delaying the next cycle, omitting } \\
\text { some scheduled cycle, or generally enlarging } \\
\text { intervals should be considered }\end{array}$ \\
\hline Low & $\begin{array}{l}\text { - Adjuvant chemotherapy in stage } \\
\text { T1A-T2bN0 with negative prognos- } \\
\text { tic features (lymphovascular infiltra- } \\
\text { tion, histological subtype). The risk } \\
\text { versus potential benefit should be } \\
\text { individually discussed with patients } \\
\text { - Adjuvant chemotherapy for patients } \\
\text { with significant comorbidities, or } \\
\text { elderly patients >70 years, should } \\
\text { be discussed and possibility omitted }\end{array}$ & - & $\begin{array}{l}\text { - Discontinuation of IO after } 2 \text { years of treatment } \\
\text { should be considered, keeping in mind the lack } \\
\text { of prospective evidence } \\
\text { - For patients ongoing with IO having stopped } \\
\text { due to toxicity, resuming might be delayed in } \\
\text { absence of disease progression } \\
\text { - Postpone antiresorptive therapy (zoledronic acid } \\
\text { and denosumab) that is not needed urgently }\end{array}$ \\
\hline
\end{tabular}

Abbreviations: G-CSF, granulocyte colony-stimulating factor; IO, immune oncology; NSCLC, nonsmall-cell lung cancer; QoL, quality of life; SCLC, nonsmall-cell lung cancer; TKI, tyrosine kinase inhibitors. 
Table 4 Summary of lymphoma/leukemia/myeloma treatment recommendations in the era of COVID-19 by disease ${ }^{34,35}$

\begin{tabular}{|c|c|}
\hline Types of cancer & Treatment recommendations (lymphoma/leukemia/myeloma) \\
\hline \multirow[t]{2}{*}{ Hodgkin's lymphoma } & $\begin{array}{l}\text { - ABVD to be used as upfront standard of care as an outpatient treatment } \\
\text { - Avoid intensive chemotherapy combinations (brentuximab plus AVD, BEACOPP) for } \\
\text { untreated patients to minimize risk of hospitalization. }\end{array}$ \\
\hline & - Consider outpatient salvage chemotherapy regimens such as GDP when possible \\
\hline \multirow[t]{2}{*}{ Non-Hodgkin's lymphoma-aggressive } & $\begin{array}{l}\text { - CHOP with rituximab for B-cell NHLs. Avoid in patient regimens for untreated aggres- } \\
\text { sive NHL, except in selected circumstances (young patients with Burkitt's lymphoma or } \\
\text { high-grade B-cell double-hit lymphoma) } \\
\text { - Administer EPOCH-R as outpatient if possible }\end{array}$ \\
\hline & $\begin{array}{l}\text { - Select outpatient salvage regimens in relapsed disease. If autologous HSCT must be } \\
\text { delayed, consider bridging with systemic therapy or localized radiotherapy }\end{array}$ \\
\hline $\begin{array}{l}\text { Non-Hodgkin's lymphoma-indolent/ } \\
\text { mantle-cell lymphoma }\end{array}$ & $\begin{array}{l}\text { - Consider deferring therapy until strongly indicated. } \\
\text { - Consider low-dose local radiotherapy(232 Gy) for localized symptomatic disease control } \\
\text { - Consider the use of less myelosuppressive/immunosuppressive regimens whenever } \\
\text { possible } \\
\text { - Refrain from anti-CD20 antibody maintenance therapy to allow for B-cell recovery }\end{array}$ \\
\hline Peripheral T-cell lymphoma & $\begin{array}{l}\text { - Standard CHOP with or without etoposide as outpatient treatment. Defer autologous } \\
\text { HSCT indefinitely } \\
\text { - In older patients with PTCL with a low chance of cure with multiagent regimens, con- } \\
\text { sider front line therapy with novel single agents }\end{array}$ \\
\hline Chronic lymphocytic leukemia & $\begin{array}{l}\text { - Asymptomatic patients-"Wait and Watch" } \\
\text { - If treatment initiation is required during the pandemic, an oral agent without the need } \\
\text { for hospitalization, infusion, or frequent clinic visits would be preferred } \\
\text { - COVID-19 negative, continue oral targeted agents but hold antibody treatments, che- } \\
\text { motherapy, and IVIG infusions } \\
\text { - COVID-19 diagnosis, hold CLL treatment with monoclonal antibodies and chemother- } \\
\text { apy but consider continuing oral targeted agents in selected patients with high risk for } \\
\text { disease flare after discontinuation }\end{array}$ \\
\hline Acute lymphoblastic leukemia & $\begin{array}{l}\text { - Curative-intent treatment of adults with ALL will require a period of inpatient manage- } \\
\text { ment and blood product support. For a curable patient, consolidation/maintenance } \\
\text { therapy unavoidable despite a risk of immunosuppression } \\
\text { - Allogeneic HSCT is potentially debatable (particularly in MRD-negative CR1) and contin- } \\
\text { gent upon response to therapy }\end{array}$ \\
\hline Acute myeloid leukemia & $\begin{array}{l}\text { - Curative-intent treatment of adults with AML will require a period of inpatient manage- } \\
\text { ment and blood product support } \\
\text { - Consider outpatient induction and consolidation when feasible with hypomethylating } \\
\text { agents } \\
\text { - Consider maintenance therapy if allogeneic HSCT is unavailable for patients who would } \\
\text { normally be eligible } \\
\text { - Consider less intensive treatment in patients with relapsed/refractory disease }\end{array}$ \\
\hline $\begin{array}{l}\text { Myeloproliferative neoplasia/myelodysplastic } \\
\text { syndrome }\end{array}$ & $\begin{array}{l}\text { - No changes to the general management of chronic MPNs, including phlebotomy, } \\
\text { hydroxyurea, interferons, and Janus kinase inhibitors } \\
\text { - Low-grade MDS, consider initiation of growth factors, such as ESAs and eltrombopag to } \\
\text { decrease transfusion need; consider delaying HMAs } \\
\text { - High-grade MDS, HMAs should be initiated or continued while definitive therapy with } \\
\text { allogeneic HSCT is delayed }\end{array}$ \\
\hline Multiple myeloma & $\begin{array}{l}\text { - For newly diagnosed MM, prefer regimens that allow for limited exposure to health care } \\
\text { facilities (i.e., allow for substitution of oral for intravenous chemotherapy, minimize dos- } \\
\text { ing frequency) } \\
\text { - Defer autologous HSCT for patients with MM and consider collecting and storing cells } \\
\text { only } \\
\text { - Continue maintenance therapy with lenalidomide or bortezomib } \\
\text { - Consider holding anti-CD38 antibody treatment in patients with stable disease or in } \\
\text { durable remission to mitigate risks of plasma-cell depletion }\end{array}$ \\
\hline
\end{tabular}

Abbreviations: ABVD, doxorubicin, bleomycin, vinblastine, dacarbazine; ALL, acute lymphoblastic leukemia; AML, acute myeloid leukemia; AVD, doxorubicin, vinblastine, and dacarbazine; BEACOPP: bleomycin, etoposide, doxorubicin hydrochloride (Adriamycin), cyclophosphamide, vincristine (Oncovin), procarbazine and prednisone; CLL, chronic lymphocytic leukemia; COVID-19, novel coronavirus disease 2019; EPOCH-R, (etoposide, prednisone, vincristine, cyclophosphamide, doxorubicin, and rituximab; ESAs, erythropoiesis-stimulating agents; HSCT, hematopoietic stem-cell transplantation; HMAs, hypomethylating agents; IVIG, intravenous immunoglobulin; MDS, myelodysplastic syndromes; MM, multiple myeloma; MPNs, myeloproliferative neoplasms; MRD, minimal residual disease; NHL, non-Hodgkin's lymphoma; PTCL, peripheral T-cell lymphoma. Adapted from: Percival et al. ${ }^{34}$ 
GDP-like regimens). If not feasible, decision regarding use of ICE/ESHAP/DHAP should be on case-to-case basis. Maintenance therapy with rituximab in indolent lymphomas may be postponed or temporarily held. Procedures such as high-dose chemotherapy and autologous hematopoietic stem-cell procedure must be decided in multidisciplinary tumor boards.

Chronic lymphocytic leukemia (CLL) patients should be treated with oral treatments and follow-up through teleconsultation is recommended. Patients in remission for $>2$ years should be recommended "Wait and Watch" strategy without the need to visit the hospital. ${ }^{33}$ Omitting, delaying, or shortening radiotherapy should be considered wherever possible. ${ }^{34}$

Additional information, guidelines, and recommendations made by international oncology societies and bodies are also available for gastrointestinal (GI) malignancies (colorectal, pancreatic, esophageal, and hepatocellcular), sarcomas, melanomas, cervical cancers, ovarian cancers, lymphomas, NSCLC, and prostate cancers..$^{30,35-44}$ In spite of all the precautions, it is possible that a cancer patient undergoing therapy might get infected with COVID-19. Such patients deserve aggressive treatment for the coronavirus infection like other noncancer patients. ${ }^{45,46}$

\section{Summary and Conclusion}

In this rapidly evolving pandemic situation, India needs to take pragmatic actions to deal with the challenges of treating cancer patients (ensuring their rights, safety, and wellbeing). Treatment decisions should be individualized based on the risk/benefit ratio for each patient. Homecare with the help of telemedicine and local physicians should be encouraged where possible. The oncology professionals are the frontline fighters who have the key responsibility of providing the best revised cancer care strategy to their patients, taking into consideration the prevailing circumstances brought about by the COVID-19 pandemic. Patients and their families should proactively participate in the decision-making process, especially by stating their preferences. Cancer patients might need additional psychological support during the COVID-19 pandemic. Ongoing clinical trials might require steps to ensure a patient friendly approach while ensuring integrity of the study data. Cancer patients need to be triaged into high, medium, or low category of risk for treatment decision-making. Telemedicine consultation services need to be ramped up to minimize hospital visits. Treatment for patients with newly diagnosed potentially curable cancer must remain a priority. Procedures with high risk of aerosol contamination must be delayed or conducted with additional precautions to safeguard the health care professionals involved. Where treatment is unlikely to improve survival meaningfully or may compromise QoL/increase risk of COVID-19 infection, a wait and watch policy can be considered. Intravenous therapies can be replaced with oral therapies if appropriate. Intensive treatment (e.g., allogenic stem-cell transplantations) should be considered only at well-equipped centers and for patients who have no other treatment options. Emergency anticancer therapy should not be denied to any patient.
Source of Funding

The manuscript writing was funded by Mylan Pharmaceuticals Private Limited.

Conflict of Interest

There are no conflicts of interest to declare.

\section{References}

1 WHO coronavirus disease (COVID-19) dashboard. Available at: https://covid19.who.int/. Accessed June 12, 2020

2 Ministry of Health and Family Welfare Government of India. COVID-19 Statewise status. Available at: https://www.mohfw. gov.in/. Accessed June 12, 2020

3 Mehta P, Parikh P, Aggarwal S, et al. Has India met this enemy before? From an eternal optimist's perspective: SARS-CoV-2. Indian J Med Sci 2020;72(1):8-12

4 Liang W, Guan W, Chen R, et al. Cancer patients in SARSCoV-2 infection: a nationwide analysis in China. Lancet Oncol 2020;21(3):335-337

5 Report of the WHO-China Joint Mission on Coronavirus Disease 2019 (COVID-19). Available at: who.int/docs/defaultsource/coronaviruse/who-china-joint-mission-on-covid-19final-report.pdf. Accessed April 29, 2020

6 Zhang L, Zhu F, Xie L, et al. Clinical characteristics of COVID-19-infected cancer patients: a retrospective case study in three hospitals within Wuhan, China. Ann Oncol 2020;31(7):894-901

7 Desai A, Sachdeva S, Parekh T, Desai R. COVID-19 and cancer: lessons from a pooled metanalysis. JCO Glob Oncol 2020;6:557-559

8 Abraham P, Aggarwal N, Babu GR, et al. Laboratory surveillance for SARS-CoV-2 in India: performance of testing \& descriptive epidemiology of detected COVID-19, January 22 - April 30, 2020. Ind J Med Res 2020;151(5):424-437

9 Lai AG, Pasea L, Banerjee A, et al. Estimated impact of the COVID-19 pandemic on cancer services and excess 1-year mortality in people with cancer and multimorbidity: near real-time data on cancer care, cancer deaths and a population-based cohort study. BMJ Open 2020;10:e043828

10 Zhou F, Yu T, Du R, et al. Clinical course and risk factors for mortality of adult inpatients with COVID-19 in Wuhan, China: a retrospective cohort study. Lancet 2020;395(10229): 1054-1062

11 Parikh P, Mehta P, Bansal S, et al. Protecting health-care professionals and workers (other than COVID-19 management facilities) from contamination during COVID-19 pandemic (March 26, 2020 - India). Int J Med Sci 2020;72(1):3-4

12 Gundavda MK, Parikh PM. Why the use of face masks by everyone outside their homes is still mandatory during the COVID19 pandemic. Indian J Med Sci 2020 (e-pub ahead of print). doi:10.25259/IJMS_311_2020

13 Parikh PM, Bapna A, Krishna MVet al. COVID-19 testing in India in comparison to the rest of the world. If Indian testing strategy was replicated in the other top 15 COVID-19 affected countries in the world, the status would be startlingly different. Indian J Med Sci 2020;72(2):107-109

14 ESMO guideline. Cancer patient management during the COVID-19 pandemic. Available at: https://www.esmo.org/ guidelines/cancer-patient-management-during-the-covid19-pandemic?hit=ehp. Accessed April 29, 2020

15 WHO-Coronavirus disease (COVID-19) advice for the public. Availableat: https://www.who.int/emergencies/diseases/novelcoronavirus-2019/advice-for-public. Accessed April 29, 2020

16 Al-Shamsi HO, Alhazzani W, Alhuraiji A, et al. A practical approach to the management of cancer patients during the novel coronavirus disease 2019 (COVID-19) 
pandemic: An International Collaborative Group. Oncologist 2020;25(6):e936-e945

17 COVID-19 rapid guideline: delivery of systemic anticancer treatments. Available at: https://www.nice.org.uk/guidance/ ng161. Accessed May 6, 2020

18 COVID-19 rapid guideline: delivery of radiotherapy. Available at: https://www.nice.org.uk/guidance/ng162. Accessed May 6, 2020

19 COVID-19 rapid guideline: hematopoietic stem cell transplantation. Available from: https://www.nice.org.uk/guidance/ ng164. Accessed May 6, 2020

20 Telemedicine Practice Guidelines. Available at: https://www. mohfw.gov.in/pdf/Telemedicine.pdf Accessed April 30, 2020

21 World Health Organization (WHO). Infection prevention and control during health care when COVID-19 is suspected. March 19, 2020. Available at: https://www.who.int/publications/i/item/10665-331495. Accessed May 5, 2020

22 American Society of Clinical Oncology. COVID-19 Provider \& Practice Information. Available at: https://www.asco.org/ asco-coronavirus-information/provider-practice-preparedness-covid-19. Accessed May 5, 2020

23 Waterhouse DM, Harvey RD, Hurley P, et al. Early impact of covid-19 on the conduct of oncology clinical trials and longterm opportunities for transformation: findings from an American Society of Clinical Oncology Survey. JCO Oncol Pract 2020;16(7):417-421

24 U.S. Food and Drug Administration. FDA Guidance on Conduct of Clinical Trials of Medical Products during COVID-19 Public Health Emergency: Guidance for Industry, Investigators, and Institutional Review Boards, March 2020. Available at: https:// www.fda.gov/regulatory-information/search-fda-guidance-documents/fda-guidance-conduct-clinical-trials-medical-products-during-covid-19-public-health-emergency. Accessed May 5, 2020

25 Sidley Austin LLP. Considerations for Sponsors of Ongoing Clinical Trials in Light of COVID-19 (Part 1). March 31, 2020. Available at: https://www.sidley.com/en/insights/newsupdates/2020/03/covid19-considerations-for-sponsors-of-ongoing-clinical-trials-in-light-of-covid19-part1. Accessed May 5, 2020

26 National Cancer Institute. General Guidance for All Trials (Both IND and Non-IND Trials). Available at: https://www. ncicirb.org/system/files/Interim_Guidance_Clinical_Trial_ Activities_Affected_\%20by_Novel_Coronavirus_3-13-2020_0. pdf. Accessed May 5, 2020

27 Parikh PM, Mehta P, Krishna Kumar MVT, et al. Clinical trials facing "serious adverse events" during the ongoing COVID-19 pandemic. Indian J Med Paediatr Oncol 2020;41(3):295-298

28 Globocan 2020fact sheet: India. Available at: https://gco.iarc. $\mathrm{fr} /$ today/data/factsheets/populations/356-india-fact-sheets. pdf. Accessed May 9, 2020

29 ESMO management and treatment adapted recommendations in the Covid-19 era: Breast cancer. Available at: https://www. esmo.org/guidelines/cancer-patient-management-duringthe-covid-19-pandemic/breast-cancer-in-the-covid-19-era. Accessed April 30, 2020

30 Updated IASO. Updated IASO Covid-19/Curfew Guidelines. Dated 25th March 2020. Available at: https://iasoindia.in/ wp-content/uploads/2020/03/Official-IASO-COVID-19Guidelines.pdf Accessed April 30, 2020

31 Recommendations for prioritization, treatment and triage of breast cancer patients during the COVID-19 pandemic. The COVID-19 pandemic breast cancer consortium. Available at: https://www.nccn.org/covid-19/pdf/The_COVID-19_Pandemic_Breast_Cancer_Consortium_Recommendations.pdf. Accessed May 8, 2019
32 ESMO management and treatment adapted recommendations in the covid-19 era: lung cancer. Available at: https://www. esmo.org/guidelines/cancer-patient-management-duringthe-covid-19-pandemic/lung-cancer-in-the-covid-19-era. Accessed May 8, 2019

33 Short-term recommendations for non-small cell lung cancer management during the COVID-19 pandemic. Available at: https://www.nccn.org/covid-19/pdf/COVID_NSCLC.pdf Accessed May 3, 2020

34 Percival MM, Lynch RC, Halpern AB, et al. Considerations for managing patients with hematologic malignancy during the COVID-19 pandemic: the Seattle Strategy. JCO Oncol Pract 2020;16(9):571-578

35 Yahalom J, Dabaja BS, Ricardi U, et al. ILROG emergency guidelines for radiation therapy of hematological malignancies during the COVID-19 pandemic. Blood 2020;135(21):1829-1832

36 Lou E, Beg S, Bergsland E, et al. Modifying practices in GI Oncology in the face of COVID-19: Recommendations from expert oncologists on minimizing patient risk. JCO Oncol Pract 2020;16(7):383-388

37 ESMO management and treatment adapted recommendations in the covid-19era:hepatocellularcarcinoma(HCC).Availableat: https://www.esmo.org/guidelines/cancer-patient-management-during-the-covid-19-pandemic/gastrointestinal-cancers-hepatocellular-carcinoma-hcc-in-the-covid-19-era. Accessed April 30, 2020

38 ESMO management and treatment adapted recommendations in the covid-19 era: sarcomas. Available at: https://www. esmo.org/guidelines/cancer-patient-management-duringthe-covid-19-pandemic/sarcomas-in-the-covid-19-era. Accessed April 30, 2020

39 ESMO management and treatment adapted recommendations in the covid-19 era: melanomas. Available at: https://www. esmo.org/guidelines/cancer-patient-management-duringthe-covid-19-pandemic/melanoma-in-the-covid-19-era. Accessed April 30, 2020

40 ESMO management and treatment adapted recommendations in the covid-19 era: cervical cancer. Available at: https://www. esmo.org/guidelines/cancer-patient-management-duringthe-covid-19-pandemic/gynaecological-malignancies-cervical-cancer-in-the-covid-19-era. Accessed April 30, 2020

41 ESMO management and treatment adapted recommendations in the covid-19 era: epithelial ovarian cancer. Available at: https://www.esmo.org/guidelines/cancer-patient-management-during-the-covid-19-pandemic/gynaecological-malignancies-epithelial-ovarian-cancer-in-the-covid-19-era. Accessed April 30, 2020

42 Principles for management of colorectal cancer patients during the COVID-19 pandemic. Available at https://www. nccn.org/covid-19/pdf/Colorectal\%20COVID-19.pdf. Accessed April 30, 2020

43 Management of prostate cancer during the COVID-19 pandemic. Available from: https://www.nccn.org/covid-19/pdf/ NCCN_PCa_COVID_guidelines.pdf. Accessed May 10, 2020

44 ESMO management and treatment adapted recommendations in the COVID-19 era: prostate cancer. Available at: https:// www.esmo.org/guidelines/cancer-patient-managementduring-the-covid-19-pandemic/genitourinary-cancers-prostate-cancer-in-the-covid-19-era . Accessed May 10, 2020

45 Gundavda KK, Parikh PM. Convalescent plasma therapy for COVID-19 still has the potential to save lives - The ICMR PLACID study dissected. Int J Mol Immuno Oncol 2021;6(1):47-49

46 Budhiraja S, Dewan A, Aggarwal R, et al. Effectiveness of convalescent plasma therapy in Indian patients with COVID-19. Blood Cells Mol Dis 2020;88:102548 